\title{
Residuos para la producción de vidrios y vitrocerámicos
}

\author{
Wastes based glasses and glass-ceramics
}

L.BARBIERI, A.CORRADI, I.LANCELLOTTI

Univiversidad de Módena

Fecha de recepción: 22-I-2001

ITALIA

\begin{abstract}
RESUMEN
Realmente la inertización, recuperación y valorización de residuos que proceden de los procesos de incineración de residuos municipales $y$ de residuos industriales son metas importantes desde el punto de vista ambiental y económico. Una tecnología alternativa capaz de superar el problema de la heterogeneidad de la composición química de los materiales de partida es el proceso de la vitrificación que es capaz de aumentar la homogeneidad y la constancia de la composición quimica del sistema y modular las propiedades a fin de la reutilización del residuo. En este artículo se presentan los resultados de vitrificación en que los vidrios fueron sometidos a tratamientos térmicos controlados diferentes, de manera que se transforman en materiales semicristalinos (también denominados vitrocerámicos) con mejores propiedades respecto a los materiales amorfos originales. En esta revisión se muestra el diseño, preparación y caracterización de vidrios y vitrocerámicos partiendo de residuos de la incineración de cenizas municipales, cenizas volantes procedentes de la producción de acero y casco de vidrio.
\end{abstract}

\begin{abstract}
SUMMARY
Actually, the inertization, recovery and valorisation of the wastes coming from municipal and industrial processes are the most important goals from the environmental and economical point of view. An alternative technology capable to overcome the problem of the dishomogeneity of the raw material chemical composition is the vitrification process that is able to increase the homogeneity and the constancy of the chemical composition of the system and to modulate the properties in order to address the reutilization of the waste. Moreover, the glasses obtained subjected to different controlled thermal treatments, can be transformed in semy- cristalline material (named glassceramics) with improved properties with respect to the parent amorphous materials. In this review the tailoring, preparation and characterization of glasses and glassceramics obtained starting from municipal incinerator grate ash, coal and steel fly ashes and glass cullet are described.
\end{abstract}

\section{INTRODUCCIÓN}

El crecimiento económico ha llegado a ser una importante meta en la sociedad actual. Las naciones, gobiernos y la sociedad en general buscan estimular sus economías para crear puestos de trabajo y para aumentar la accesibilidad a productos y tecnologías que mejoren la calidad de vida. En este sentido, el sector industrial juega un papel importante en el proceso de desarrollo económico en el mundo. No obstante, los resultados positivos económicos y sociales del crecimiento

\section{INTRODUCTION}

Economic growth has become the goal of every society. Nations, governments and societies in general seek to stimulate their economies, to create jobs, to increase the accessibility of products and technologies that enhances the quality of life. In this sense, industrial sector plays an important role in the process of economic development in the world. The positive economic and social results of industrial growth have been accompanied by the 
industrial han sido acompañados por un efecto contrario: la crisis medioambiental global. La tecnología creciente basada en la industria ha tenido un impacto ambiental importante, siendo la industria el consumidor principal de recursos naturales y el contribuyente más importante a la contaminación total (residuos sólidos, gases, aguas residuales, etc. ...). La solución de esta paradoja evidente entre el desarrollo económico y la crisis ambiental global puede ser resuelta mediante un desarrollo sostenible. $\mathrm{La}$ recuperación y valorización de los materiales residuales y subproductos que proceden de los procesos municipales e industriales han llegado a ser un problema cada vez más urgente para el próximo futuro. A la vista de las normas ambientales que apuntan a limitar el uso de escombreras y basureros al aire libre, el desarrollo de técnicas de reciclado capaces de utilizar los residuos en nuevos productos vendibles adquiere una importancia creciente. A causa de su composición química compleja y la presencia en algunos casos de metales pesados en los residuos (residuos tóxicos y peligrosos), la obtención de vidrios y vitrocerámicos (1-7) puede representar una buena oportunidad para el aprovechamiento de dichos residuos. Las razones principales yacen en el hecho de que las tecnologías de la vitrificación y devitrificación controlada son capaces de aumentar la homogeneidad y la constancia de la composición química del sistema y modular las propiedades cuando se utilizan como técnicas de reciclado. La vitrificación se basa en que los materiales en bruto se fundan a unos $1.450^{\circ} \mathrm{C}$ moldeándose en el proceso de enfriamiento del fundido. Cuando el material "amorfo" se somete a nucleación controlada y a cristalización inducida mediante un tratamiento térmico (devitrificación), se forma un material semicristalino, denominado vitrocerámico. El interés especial que rodea a los vidrios y vitrocerámicos se debe a sus características peculiares, tal como la capacidad de la fase vítrea para englobar en su red metales pesados, estabilidad química, mecánica, dureza de superficie y coeficientes bajos de expansión térmica. Estos aspectos hacen que estos materiales se puedan adaptar fácilmente para fines de reciclado de residuos industriales.

El propósito de esta revisión es describir el diseño, preparación y caracterización de varios vidrios y vitrocerámicos obtenidos por el reciclado de residuos.

\section{PROCEDIMIENTOEXPERIMENTAL}

\section{1. Residuos seleccionados}

Se han seleccionado residuos procedentes de la incineración de residuos sólidos urbanos, tales como carbón vítreo, cenizas volantes y casco de vidrio. reversal effect: global environmental crisis. The growing technology-based industry has had an important environmental impact, being the industry the major consumer of natural resources and the major contributor to the overall pollution load (solid residues, gases, waste waters). The resolution of this apparent paradox between the economical development and the environmental global crisis can be addressed by the sustainable development. Recovery and valorization of by-products and waste material coming from municipal and industrial processes has become a more and more urgent problem for the next future. In the light of environmental norms aiming at limiting the use of the dump, the development of new recycling techniques capable to exploit the wastes into new marketable products acquires an increasing importance. Because of the complex chemical composition and the presence in some cases more important than in others of heavy metals in the wastes (hazardous special or special waste), the obtention of waste-based glasses and glass-ceramics (1-7) may represent a good opportunity. The main reasons lie in the fact that the vitrification and devitrification technologies are able to increase the homogeneity and the constancy of the chemical composition of the system and to modulate the properties in order to address the reutilization. The vitrification consists in the raw material melting at about $1.450^{\circ} \mathrm{C}$; when the amorphous material is subjected to controlled nucleation and crystallisation, induced through a heat treatment (devitrification), it is transformed into a semicrystalline material, named glass-ceramic. The great interest surrounding glass and glass-ceramics in widespread fields is due to their peculiar characteristics such as capability of the glass network to embed the heavy metals, chemical and mechanical durability, surface hardness, low thermal expansion coefficients. These features make the above mentioned materials easily adapted to practical utilization.

The purpose of this review is to describe the tailoring, preparation and characterization of several glasses and glass-ceramics made by using different kind of wastes.

\section{EXPERIMENTAL PROCEDURE}

\subsection{Wastes used}

Special waste (municipal incinerator grate ash, coal fly ash and glass cullet) and a hazardous special waste (steel plant fly ash) have been mixed together in order to obtain different glasses and glass-ceramics. 
También un residuo especial peligroso de una planta de acería se ha mezclado con los anteriores para obtener vidrios y vitrocerámicos. La ceniza procedente de incineradora es el residuo sólido más importante en dicho proceso (la cantidad suele ser de $300 \mathrm{~kg}$ por cada $1.000 \mathrm{~kg}$ de residuo sólido urbano). Esta tecnología, en los países industrializados llega a ser cada vez más usada ya que permite la reducción de volumen de los residuos, la destrucción completa de toda la materia orgánica, la destoxificación de los contaminantes inorgánicos y el uso de la energía producida en la incineración y que está contenida en estos tipos de residuos.

La mayoría de las plantas eléctricas térmicas queman carbón fósil en forma de antracita o lignito quedeja un residuo de ceniza después de la combustión. La ceniza volante (las partículas más finas) es el material transportado con los gases de humos hasta ser recuperados por filtros y constituye el $80 \%$ del residuo total de las plantas de producción de energía eléctrica, permaneciendo un $20 \%$ como ceniza conocida con el nombre de "ceniza de fondo". Alrededor de un promedio de $1 \mathrm{~kg}$ de combustible de carbón da origen a unos $0,15 \mathrm{~kg}$ de ceniza, incluyendo además partículas inquemadas de carbón (6-24 g) (8).

El vidrio de casco residual es uno de los productos recuperados por el programa comunitario de reciclado que supuso unas 700.000 toneladas de vidrio en 1998 en Italia (9). Este vidrio reciclado ha permitido un gran ahorro de costes $(0,013$ euros $/ \mathrm{kg}$ en el caso del almacenamiento en escombreras y unos 0,077 euros $/ \mathrm{kg}$ por el reciclado). Los beneficios que se derivan del uso de casco de vidrio en la producción industrial de vidrio (ahorro de materias primas, reducción de energía y de contaminación durante el proceso de fusión) son relativos al pre- tratamiento de purificación (eliminación de oxido ferroso, materiales cerámicos y orgánicos). Considerando que en ambos casos, en Italia, el programa comunitario de reciclado no prevé la separación de vidrio sobre la base del color para obtener un producto final de calidad alta, la recuperación de casco por la industria del vidrio se ha limitado.

El sector metalúrgico italiano es muy importante, con una producción anual de 25,106 ton. Los procesos principales de producción abarcan desde los minerales de hierro (alto horno) hasta el acero residual ( horno eléctrico de arco). Las emisiones eléctricas de este tipo de ciclo son: $\mathrm{CO}, \mathrm{CO}_{2}$ y polvos de filtros de mangas (6,5-21 kg de polvo por cada tonelada de metal fundido). El polvo residual tiene una gama amplia de composiciones que depende de la carga metálica y del tipo de acero. El acero al carbón da lugar principalmente a polvos enriquecido en $\mathrm{Fe}, \mathrm{Zn}, \mathrm{Pb}$ y
Municipal incinerator grate ash is the most important solid residue, as regards the amount produced $(300 \mathrm{~kg}$ for $1.000 \mathrm{~kg}$ of waste burnt), of the municipal wastes incineration process. This technology, in the industrialized countries, is becoming more and more in use thanks to the volume reduction of the wastes, complete destruction of all organic matter, detoxification of inorganic pollutants present in the waste and use of the energy contained in the waste stream.

The majority of thermal power stations burn fossil carbon in the form of anthracite or lignite which leaves an ash residue after combustion. The fly ash (finer particles) is the material transported with the flue gases until recovered by filtered: this amount constitutes the $80 \%$ of the total residue from the electric power plants, the remaining $20 \%$ being known as bottom ash. On average $1 \mathrm{~kg}$ of carbon fuel gives rise to $0.15 \mathrm{~kg}$ of ash, including the un-burnt carbon particles (6-24 g) (8).

Glass cullet is one of the products recovered by the community recycling program that, by the collecting of about 700.000 tons of glass in 1998 in Italy (9), has allowed to save money $(0.013 \mathrm{eu} / \mathrm{kg}$ for the disposal in landfill against $0.077 \mathrm{eu} / \mathrm{kg}$ for collecting). The benefits deriving from the glass cullet use in the production of the industrial glass (saving of raw material, reduction of energy and pollution during the melting process) are strictly related to the purification pre-treatment (elimination of ferrous, ceramic and organic material). By considering that both in Italy the community recycling program does not foresee the glass separation on the base of the color and the final product high quality required, the cullet recovery in the glass industry is limited.

The Italian metallurgical sector is very important with a yearly production of about $25 \cdot 10^{6}$ ton. The main production processes are from iron ores (blast furnace) and from steel scraps (electric arc furnace). The electric cycle emissions are $\mathrm{CO}, \mathrm{CO}_{2}$ and a sleeve filter powder $16.5-21 \mathrm{~kg}$ of powder from 1 ton of melted metal). The waste powder has a wide range of compositions depending both on the metallic charge and on the kind of steel. The carbon steel gives mainly rise to powders enriched in $\mathrm{Fe}, \mathrm{Zn}, \mathrm{Pb}$ and $\mathrm{Mn}$, used in this work, and those originated from 
$\mathrm{Mn}$, como el usado en este trabajo, y los originarios del acero inoxidable están constituidos por $\mathrm{Fe}, \mathrm{Cr}$ y $\mathrm{Ni}$. Cuatro tipologías de proceso están en uso para la recuperación y tratamiento de polvo de acerías: pirometalurgia, hidrometalurgia, vitrificación y limpieza centrífuga.

\subsection{Caracterización}

Con objeto de facilitar el diseño de vidrios y vitrocerámicos basados en residuo, deben siempre tenerse en cuenta los aspectos tecnológicos y económicos siguientes:

- La composición debe diseñarse para aumentar al máximo la cantidad de residuo reciclado en la composición del material final.

- El residuo que debe reciclarse debe tener una composición homogénea y estable, así como producirse en cantidades suficientes que justifique los gastos de una planta de producción.

- Los aditivos requeridos para diseñar una composición deben ser baratos (es decir, otros residuos o subproductos)

- Las propiedades de los vidrios y vitrocerámicos deben tener tales propiedades y aplicaciones como para favorecer la explotación comercial en grandes mercados y capaces de competir en calidad y costo con los productos ya existentes.

Si las consideraciones antes mencionadas no son tenidas en cuenta, la producción de estos materiales sería económicamente injustificada y la reducción del impacto ambiental no se lograría.

Debido a la composición química compleja de los residuos e incluso gracias a que la mayoría de ellos contiene los componentes típicos de las composiciones de materiales vítreos, su mezclado puede representar una buena solución. De esta manera, cada residuo puede contribuir a abastecer una cantidad apropiada de agente formador de la red vítrea $\left(\mathrm{SiO}_{2}\right.$, $\left.\mathrm{Al}_{2} \mathrm{O}_{3} \ldots\right)$, elementos modificadores $\left(\mathrm{Na}_{2} \mathrm{O}, \mathrm{K}_{2} \mathrm{O} \ldots\right)$ y estabilizadores $(\mathrm{CaO}, \mathrm{MgO}, \mathrm{ZnO}, \mathrm{PbO}$...) que son los componentes que dan lugar a vidrios de adecuadas características.

El primer aspecto investigado en este trabajo ha sido el estudio teórico de la tendencia de los vidrios para desarrollar fases cristalinas y producir vitrocerámicos (método de Ginsberg). Con el fin de lograr un conocimiento completo de los vidrios y vitrocerámicos obtenidos a partir de residuos es the stainless steel are constituted by $\mathrm{Fe}, \mathrm{Cr}$ and $\mathrm{Ni}$. Four process typologies are in use for the recovery and treatment of this steel powder: pyrometallurgy, hydrometallurgy, vitrification and centrifugal cleaning.

\subsection{Characterisation}

In order to design wastes-based glasses and glassceramics, certain technological and economical aspects should be taken into account:

\section{- The composition must be designed to optimize the} amount of waste in the batch.

- The waste should be recycled as-is, have a reasonably constant composition and be produced in quantities such that the expenses for the production plant are justify.

- The additives required to obtain a composition suitable for vitrification and crystallisation should be inexpensive (i.e. other wastes or by-products).

- The properties of the final glasses and glassceramics should be such as to favor the commercial exploitation in large markets and able to compete in quality and cost with the already existing products.

If the above mentioned considerations are not taken into account, the production of these materials would be economically unjustified and the reduction of environmental impact would not be achieved.

Because of the complex chemical composition of the wastes, but thanks to the fact that most of them contain the typical constituents of glassy materials, their mixing may represent a good solution. In this way each waste may contribute to supply an appropriate quantity of vitrifying ( $\mathrm{SiO}_{2}, \mathrm{Al}_{2} \mathrm{O}_{3}$...), melting $\left(\mathrm{Na}_{2} \mathrm{O}, \mathrm{K}_{2} \mathrm{O}\right.$...) and stabilizing ( $\mathrm{CaO}, \mathrm{MgO}$, $\mathrm{ZnO}, \mathrm{PbO}$...) agents in the final glass leading to suitable physical-chemical characteristics.

The first aspect examined in this work has been the theoretical study of the formulated glasses tendency to develop glass-ceramics (Ginsberg approach). In order to reach a complete knowledge of these wastebased glasses and glass-ceramics it is necessary to know the properties of the quenched glasses and 
necesario saber si las propiedades de los vidrios de partida u originales con métodos térmicos y termomecánicos (ATD y dilatometría), difracción de rayos $\mathrm{X}(\mathrm{DRX})$ de polvo y microscopía electrónica de barrido (SEM).

En los párrafos siguientes se discutirá la producción de este tipo de vidrios y vitrocerámicos en el sistema: cenizas volantes de incineradoras de residuos municipales, cenizas volantes procedentes de centrales térmicas de carbón y casco de vidrio del sistema de reciclado urbano. Todos los vidrios han sido obtenidos por fusión, a temperaturas de $1.450^{\circ} \mathrm{C}$, de mezclas de polvos en crisoles refractarios y enfriados bruscamente en el aire.

\section{RESULTADOS Y DISCUSIÓN}

\subsection{Análisis químico de las materias primas residuales}

Como antes se ha señalado, un punto de partida fundamental para adaptar los residuos a la producción de vidrios es el control estricto de la composición química, porque las mezclas tienen que contener los componentes típicos de vidrios estables, en particular óxidos de Si y Al. Por esta razón, los materiales de residuos considerados en este trabajo se han analizado por la técnica de Espectrometría de Plasma Acoplado Inductivamente (ICP). A partir de la Tabla 1 se ve evidente que el residuo más adecuado para desarrollar un material

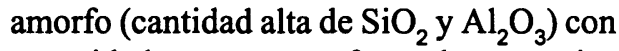
capacidad para ser transformado en un vitrocerámico (cantidad alta de $\mathrm{CaO}$ ) es la ceniza de incineradora. Por el contrario, la ceniza volante de acería estando constituída principalmente por óxidos de $\mathrm{Fe}$ y $\mathrm{Zn}$, necesita ser mezclada con una elevada cantidad de casco de vidrio residual.

\subsection{Estudio teórico de la cristalización de vidrios formulados a base de residuos}

La aproximación teórica de Ginsberg, que se sigue para el diseño de materiales de tipo petrúrgico, ha sido aplicada para estudiar la capacidad para devitrificar de los diferentes vidrios aquí considerados (10) basándose en su composición química expresada en \% peso. En la Figura 1 se representa el diagrama triangular a partir del cual es posible tener una idea del papel que juegan los diferentes cationes en el proceso de cristalización. Los vértices del diagrama corresponden a las siguientes sumas de óxidos: crystallized material which can be determined with sophisticated equipment, such as thermal and thermomechanical instruments (DTA and dilatometer), X-ray powder diffractometer (XRD), scanning electron microscope (SEM).

In the following sessions will be discussed municipal grate ash or coal fly ash and glass cullet system, steel fly ash and glass cullet or grate ash system. All the glasses have been obtained by melting the powdered batches in refractory crucibles at about $1.450^{\circ} \mathrm{C}$ and quenching them in air.

\section{RESULTS AND DISCUSSION}

\subsection{Chemical analysis of the waste raw materials}

As above underline, a fundamental starting point to tailor a wastes-based glass is the chemical composition because the mixtures have to contain the typical constituents of a glass, in particular Si and Al oxides. For this reason the waste material considered in this work have been subjected to Inductively Coupled Plasma (ICP) Spectrometry. From Table 1 it appears evident that the most adequate waste to develop an amorphous material (high amount of $\mathrm{SiO}_{2}$ and $\mathrm{Al}_{2} \mathrm{O}_{3}$ ) capable to be transformed into a glass-ceramic (high amount of $\mathrm{CaO})$ is the incinerator grate ash. On the contrary the steel fly ash being constituted mainly of $\mathrm{Fe}$ and $\mathrm{Zn}$ oxides needs to be mixed with a high amount of glass cullet.

\subsection{Crystallisation theoretical study of the formulated waste-based glasses}

Ginsberg theoretical approach, employed for petrological glass-ceramics, was applied in order to study the capability to devitrify of the different glasses (10) on the bases of their chemical composition expressed in oxide wt\%. In Figure 1 is reported the triangular diagram from which it is possible to have an idea of the role played by the cations in the crystallization process. The diagram vertexes group the oxides presenting the same role:

$$
\mathrm{Sal}=\mathrm{SiO}_{2}+\mathrm{Al}_{2} \mathrm{O}_{3} ; \mathrm{Cafem}=\mathrm{CaO}+\left(\mathrm{FeO} \text { y } \mathrm{Fe}_{2} \mathrm{O}_{3}\right)+\mathrm{MgO} ; \mathrm{Alk}=\mathrm{Na}_{2} \mathrm{O}+\mathrm{K}_{2} \mathrm{O}
$$


TABLA $1 /$ TABLE 1

Composición química promedio de los residuos en \% en peso $\pm 0,1$ en óxidos (resultados de IPC) comparados con los vidrios de usos domésticos (\% en peso $\pm 0,1$ (IPC)) / (Average chemical composition of the phases in $w t \%+0.1$ oxides (IPC) compared to that of glasses for domestic uses)

\begin{tabular}{|c|c|c|c|c|c|}
\hline $\begin{array}{c}\text { Materia prima } \\
\text { Raw material } \\
\text { Oxido } \\
\text { Oxide }\end{array}$ & $\begin{array}{c}\text { Ceniza de } \\
\text { incineradora } \\
\text { Incinerator grate } \\
\text { ash }\end{array}$ & $\begin{array}{c}\text { Ceniza volante de } \\
\text { carbón } \\
\text { Coal fly ash }\end{array}$ & $\begin{array}{c}\text { Ceniza volante de } \\
\text { aceria } \\
\text { Steel fly ash }\end{array}$ & $\begin{array}{c}\text { Casco de vidrio } \\
\text { Glass cullet }\end{array}$ & $\begin{array}{c}\text { Vidrios de usos } \\
\text { domésticos } \\
\text { Glasses for domestic } \\
\text { uses }\end{array}$ \\
\hline $\mathrm{SiO}_{2}$ & 43 & 15 & 3,8 & 70 & $70-75$ \\
\hline $\mathrm{Al}_{2} \mathrm{O}_{3}$ & 9,5 & 7,1 & 1,1 & 2,1 & $0,2-5$ \\
\hline $\mathrm{CaO}$ & 23 & 23 & 5,8 & 12 & $5-10$ \\
\hline $\mathrm{MgO}$ & 2,2 & 1,4 & 3,2 & 2,7 & $1-5$ \\
\hline $\mathrm{Na}_{2} \mathrm{O}$ & 6.1 & 0,90 & 1,4 & 12 & $13-17$ \\
\hline $\mathrm{K}_{2} \mathrm{O}$ & 1,4 & 0,40 & 0,76 & 0,30 & $\left(\mathrm{Na}_{2} \mathrm{O}+\mathrm{K}_{2} \mathrm{O}\right)$ \\
\hline $\mathrm{Fe}_{2} \mathrm{O}_{3} *$ & 1,4 & 3,8 & +5 & 0,30 & $13-17$ \\
\hline $\mathrm{ZnO}$ & 0,32 & nd & 25 & 0,10 & $0,04-1$ \\
\hline $\mathrm{MnO}$ & nd & n.d & 3,1 & n.d & - \\
\hline $\mathrm{PbO}$ & n.d. & nd & 2,7 & 0,07 & - \\
\hline $\mathrm{LOI} * *$ & 8,0 & 45 & 9,0 & 0,00 & - \\
\hline
\end{tabular}

* La suma $\left(\mathrm{FeO}+\mathrm{Fe}_{2} \mathrm{O}_{3}\right)$ se expresa como $\mathrm{Fe}_{2} \mathrm{O}_{3}$

** Pérdida de peso por ignición debida al $\mathrm{C}$ y al $\mathrm{S}$ principalmente en el caso de la ceniza volante de carbón con respecto a la ceniza de incineradora.

* Total $\mathrm{Fe}\left(\mathrm{Fe}_{2} \mathrm{O}_{3}+\mathrm{FeO}\right)$ is expressed as $\mathrm{Fe}_{2} \mathrm{O}_{3}$

** LOI due to the presence of $C$ and $S$ mainly in the coal fly ash with respect to the incinerator grate ash.

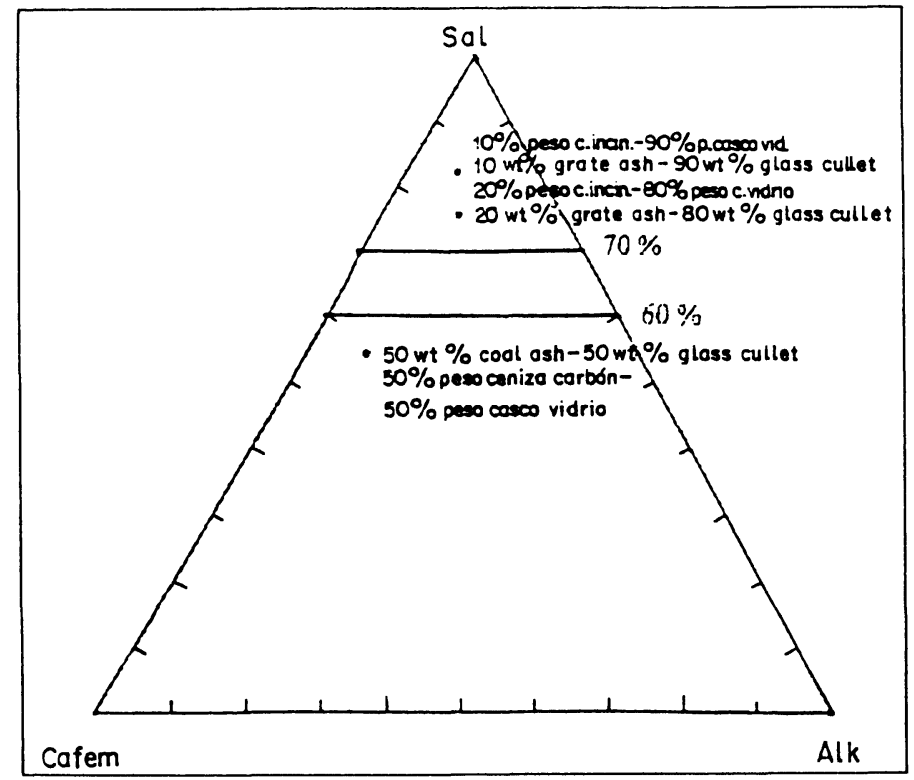

Figura 1.- Diagrama de Ginsberg para los vidrios estudiados.

Figure 1.- Ginsberg diagram for the glasses studied. 
Como puede comprobarse en la Figura 1, tres composiciones no caen en la zona marcada 60-70 que Ginsberg predice para la formación de vidrios. Como es bien conocido, el contenido alto de los óxidos modificadores debilita la red vítrea haciéndola muy débil (composición que contiene el $50 \%$ peso de ceniza volante de carbón), mientras que por encima del $70 \%$ de $\mathrm{SiO}_{2}$ la red llega a tener una estructura rígida haciendo las operaciones de procesamiento demasiado difíciles (composiciones con el 10 y $20 \%$ peso de ceniza de incineradora).

\subsection{Caracterización de vidrios del sistema: ceniza de incineradora municipal/casco de vidrio}

Diferentes vidrios se han mezclado, como antes se ha comentado, con cenizas de incineradoras de residuos municipales y casco de vidrio en diferentes relaciones (desde el 10 al 100\% de ceniza). La influencia de las diferentes composiciones es particularmente evidente con los datos experimentales enumerados en la Tabla 2.

Los experimentos de ATD han mostrado que el casco de vidrio es un vidrio muy estable a causa de la
As evidenced by Figure 1, three compositions only do not fall in the marked 60-70 band which Ginsberg predicts optimized for glass formation. As a matter of fact, below this zone the high content of modifier oxides weakens the glass network making it very mobile (composition containing $50 \mathrm{wt} \%$ of coal fly ash), while above $70 \% \mathrm{SiO}_{2}$ the network becomes such a rigid structure to make the processing operations too difficult (compositions with 10 and 20 $w t \%$ of grate ash).

\subsection{Characterization of municipal incinerator grate ash and glass cullet system}

Different glasses have been prepared as above described by mixing municipal incinerator grate ash with glass cullet in different ratio (from 10 to 100 $w t \%$ of ash). The influence of the different compositions is particularly evident in the main experimental data listed in Table 2.

DTA experiments showed that the glass cullet is a very stable glass because of the absence of the

TABLA 2 / TABLE 2

Propiedades térmicas y termomecánicas de los vidrios estudiados y fases cristalinas principales en los correspondientes vitrocerámicos / (Thermal and thermomechanical properties of the glasses studied and main crystalline phases in the corresponding glass-ceramics)

\begin{tabular}{|l|l|l|l|l|l|}
\hline $\begin{array}{l}\text { Propiedad } \\
\text { Property }\end{array}$ & $\mathrm{T}_{\mathbf{g}(\mathrm{DTADL})\left({ }^{\circ} \mathrm{C}\right)}$ & $\mathrm{T}_{\mathbf{g}(\mathrm{DE})\left({ }^{\circ} \mathrm{C}\right)}$ & $\mathrm{T}_{\mathrm{c}(\mathrm{DTA})}$ & $\left.\alpha_{100-500 \cdot 10^{6}\left({ }^{\circ} \mathrm{C}^{-1}\right)}\right)$ & $\begin{array}{l}\text { Principales fases } \\
\text { cristalinas } \\
\text { ifain crystalline } \\
\text { phases }\end{array}$ \\
\hline $\begin{array}{l}\text { Ceniza de } \\
\text { incineradora } \\
\text { \% peso } \\
\text { Grate ash wt\% }\end{array}$ & & & & & \\
\hline 0 & & & & & \\
\hline 10 & $535 / 560$ & 633 & - & 10.17 & Ninguno \\
\hline 20 & $562 / 576$ & 653 & $889 \mathrm{~s}$ & 10.11 & $\mathrm{~W}$ \\
\hline 30 & $570 / 587$ & 662 & $888 \mathrm{~s}$ & 9.98 & $\mathrm{~W}$ \\
\hline 40 & $590 / 578$ & 660 & $897 \mathrm{~s}$ & 10.00 & $\mathrm{~W}$ \\
\hline 50 & $600 / 587$ & 681 & $892 \mathrm{~m}$ & 9.73 & $\mathrm{~W}$ \\
\hline 60 & $610 / 607$ & 696 & $905 \mathrm{~m}$ & 9.26 & $\mathrm{~W}+\mathrm{D} / \mathrm{Au}$ \\
\hline 70 & $610 / 620$ & 708 & $933 \mathrm{~m}$ & 9.87 & $\mathrm{~W}+\mathrm{D} / \mathrm{Au}$ \\
\hline 80 & $628 / 616$ & 704 & $906 \mathrm{~b}$ & 9.32 & $\mathrm{~W}+\mathrm{D} / \mathrm{Au}+\mathrm{A}$ \\
\hline 90 & $630 / 620$ & 700 & $939 \mathrm{~b}$ & 9.90 & $\mathrm{~W}+\mathrm{D} / \mathrm{Au}+\mathrm{A}$ \\
\hline 100 & $632 /-$ & - & $937 \mathrm{~b}$ & 9.84 & $\mathrm{~W}+\mathrm{D} / \mathrm{Au}+\mathrm{A}$ \\
\hline
\end{tabular}

$\mathrm{s}=$ pequeño; $\mathrm{m}=$ mediano; $\mathrm{b}=$ grande

$\mathrm{W}=$ wollastonita; $\mathrm{D}=$ diópsido; $\mathrm{Au}=$ augita; $\mathrm{A}=$ anortita rica en sodio

$s=$ small $; m=$ medium $; b=$ high

$W=$ wollastonite $;=$ diopside; $A u=$ augite; $A=$ anorthite rica sodian 
ausencia de picos de cristalización. Se desarrolla, sin embargo, un pico en el intervalo de $890-940^{\circ} \mathrm{C}$ que llega a ser más agudo (desde pequeño a grande) al aumentar la cantidad de ceniza de incineradora en la mezcla binaria. La temperatura de transición vítrea, $T_{g}$, y la de reblandecirniento, $T_{s}$, generalmente aumentan con la adición de ceniza de incineradora; es decir, el contenido de $\mathrm{CaO}, \mathrm{Al}_{2} \mathrm{O}_{3}$ y $\mathrm{Fe}_{2} \mathrm{O}_{3}$ aumenta con respecto a los óxidos alcalinos, determinando una refractariedad mayor en este tipo de vidrios.

Asimismo, el coeficiente de expansión térmica disminuye agregando ceniza, lo que se debe a la disminución en el contenido de óxidos de metales alcalinos que debilitan la red vítrea (véase en particular la comparación entre el 0 y el $100 \%$ en peso de ceniza). El difractograma de DRX de los vidrios de partida enfriados bruscamente presenta una amplia banda típica del estado amorfo. Un aumento progresivo de la reflexión atribuida a fases cristalinas diferentes se observa dependiendo de la composición del vitrocerárnico y de su tratamiento térmico. A partir de las fases cristalinas principales que se muestran en la Tabla 2, la wollastonita $\left(\mathrm{CaSiO}_{3}\right)$ es la única fase presente hasta una adición del $40 \%$ de ceniza de incineradora. Aparecen además cristales de diopsido y/ 0 augita (fórmula general: $\mathrm{Ca}(\mathrm{Mg}, \mathrm{Fe}, \mathrm{Al})(\mathrm{Si}, \mathrm{Al})_{2} \mathrm{O}_{6}$ $y$ anortita rica en sodio $\left((\mathrm{Ca}, \mathrm{Na})(\mathrm{Si}, \mathrm{Al})_{4} \mathrm{O}_{8}\right) . \mathrm{El}$ análisis por SEM muestra una superficie de cristalización con la formación de cristales aciculares y dendríticos de wollastonita y diopsido/augita, respectivamente, homogéneamente dispersos en la matriz del vidrio (Figura 2).

\subsection{Caracterización de cenizas de carbón en el sistema ceniza volante/casco de vidrio}

Hasta el $50 \%$ peso de carbón de la ceniza volante se ha usado para obtener materiales amorfos por mezclado de este tipo de residuo con casco de vidrio. Al aumentar la cantidad de la ceniza e introduciendo en la mezcla un $30 \%$ peso de dolomita (como el residuo de operaciones minerales de extracción) se ayuda a la cristalización y la refractariedad de los vidrios. Esto se debe al aumento del contenido en $\mathrm{CaO}, \mathrm{MgO}, \mathrm{Al}_{2} \mathrm{O}_{3} \mathrm{y}$ $\mathrm{Fe}_{2} \mathrm{O}_{3}$ que afecta al comportamiento de cristalización en el intervalo $800-900^{\circ} \mathrm{C}$ y cambiando la temperatura de transición vítrea que cambia en el intervalo $550-650^{\circ} \mathrm{C}$ hacia valores más altos (Figura 3).

Un aumento en la tendencia hacia la cristalización, determinado por ATD, se confirma por el método de DRX, a partir de las muestras tratadas térmicamente (temperatura desde 900 a $1.100^{\circ} \mathrm{C}$ para diferentes tiempos de tratamiento desde $30 \mathrm{~min}$ a $24 \mathrm{~h}$ ), en que es evidente un aumento progresivo en la intensidad de las reflexiones, atribuido a las diferentes fases cristalinas, crystallization peak $T_{c}$. This exothermic peak, develops in the $890-940{ }^{\circ} \mathrm{C}$ range and becomes sharper and sharper (from small to big) by increasing the grate ash amount. Glass transition, $T_{g}$, and softening, $T_{s}$, temperatures generally increase by increasing the grate ash percentage, i.e. the $\mathrm{CaO}, \mathrm{Al}_{2} \mathrm{O}_{3}$ and $\mathrm{Fe}_{2} \mathrm{O}_{3}$ content with respect to the alkaline oxides, determining a refractoriness increase of the glasses. As far as the thermal expansion coefficient, $\alpha$, is concerned, the decrease of this parameter by adding the ash is due to the decrease in the alkaline-metals content which weaken the glassy network (see in particular the comparison between 0 and $100 w t \%$ grate ash). The XRD patterns of the as-quenched glasses present the broad band typical of the amorphous state. $A$ progressive increase of the reflection attributed to different crystalline phases is observed depending on the glass-ceramic composition and the thermal treatment. From the main crystalline phases reported in Table 2, the wollastonite $\left(\mathrm{CaSiO}_{3}\right)$ is the only phase present up to the addition of $40 \mathrm{wt} \%$ of grate ash. Over, also crystals of diopside and/or augite (general formula: $\left.\mathrm{Ca}(\mathrm{Mg}, \mathrm{Fe}, \mathrm{Al})(\mathrm{Si}, \mathrm{Al})_{2} \mathrm{O}_{6}\right)$, and sodium anorthite $\left((\mathrm{Ca}, \mathrm{Na})(\mathrm{Si}, \mathrm{Al}){ }_{4} \mathrm{O}_{\theta}\right)$ precipitate. SEM analysis shows a surface crystallization mechanism with the formation of acicular and dendritic crystals of wollastonite and diopside/ augite, respectively, homogeneously dispersed into the glass matrix (Figure 2).

\subsection{Characterization of coal fly ash and glass cullet system.}

Up to $50 w t \%$ of coal fly ash has been used to obtain amorphous material by mixing this kind of waste with glass cullet. By increasing the amount of the ash and inserting in the batch a 30 wt\% of dolomite (as waste of mineral extraction operations) the crystallization is helped and the refractoriness of the glasses increases. This is due to the increase of $\mathrm{CaO}$, $\mathrm{MgO}, \mathrm{Al}_{2} \mathrm{O}_{3}$ and $\mathrm{Fe}_{2} \mathrm{O}_{3}$ that in the thermal behavior acts marking the crystallization peak in the $800-900{ }^{\circ} \mathrm{C}$ range and shifting the glass transition temperature falling in the $550-650^{\circ} \mathrm{C}$ to higher values (Figure 3).

The increase in the tendency towards crystallization, determined by DTA, is confirmed by the XRD patterns, recorded on several thermal treated samples (temperatures from 900 to $1.100{ }^{\circ} \mathrm{C}$ for different times from $30 \mathrm{~min}$ to $24 \mathrm{~h}$ ), in which it is evident a progressive increase in intensity of the reflections, attributed to the different crystalline 
dependiendo de la composición y el tratamiento térmico. Las fases cristalinas más comunes desarrolladas son en este caso: pseudowollastonita $\left(\mathrm{pw}=\mathrm{CaSiO}_{3}\right.$ y piroxeno $(\mathrm{p}=$ diópsido $\mathrm{Ca}(\mathrm{Mg}, \mathrm{Al})$ $(\mathrm{Si}, \mathrm{Al})_{2} \mathrm{O}_{6}$ y/o augita $\left.\mathrm{Ca}\left(\mathrm{Mg}, \mathrm{Fe}^{3+}, \mathrm{Al}\right)(\mathrm{Si}, \mathrm{Al})_{2} \mathrm{O}_{6}\right)$ junto con espinelas de hierro ( $\mathrm{s}=$ magnetita $\mathrm{Fe}_{3} \mathrm{O}_{4}$ y/o magnesioferrita $\mathrm{MgFe}_{2} \mathrm{O}_{4}$ y/o maghemita $\mathrm{Fe}_{2} \mathrm{O}_{3}$ ) como se observa en la Figura 4.

\subsection{Caracterización de cenizas de acería y casco de} vidrio 0 sistema de ceniza de incineradora/casco de vidrio/ceniza de acería

Se ha usada en este caso una mezcla de casco de vidrio con ceniza de incineradora para crear la red vítrea en el polvo de acería introducido en un $10 \%$ peso.

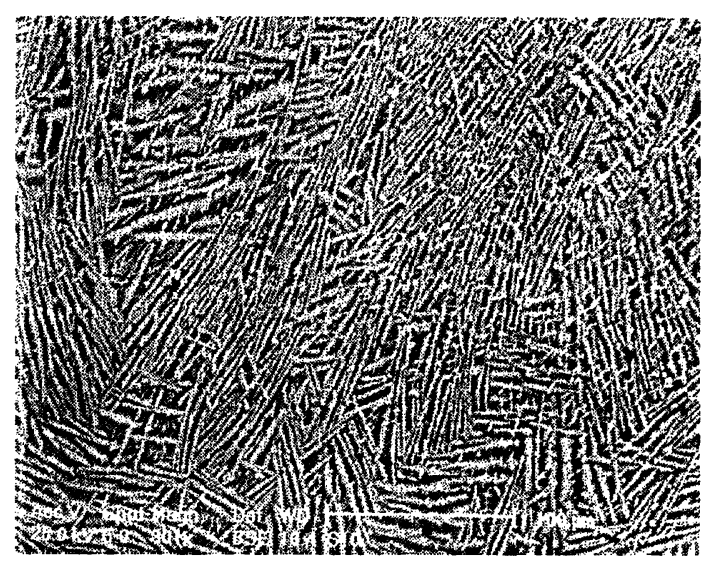

Figura 2.-Micrografia del vitrocerámico $\left(1.000^{\circ} \mathrm{C} / 8 \mathrm{~h}\right)$ conteniendo ceniza de incineradora (x 300).

Figure 2.- Micrograph of glass-ceramic $\left(1.000^{\circ} \mathrm{C} / 8 \mathrm{~h}\right)$ containing only grate ash $(300 x)$. phases, depending upon the composition and the thermal treatment. Common crystalline phases develop, as pseudowollastonite $\left(\mathrm{pw}=\mathrm{CaSiO}_{3}\right)$ and pyroxene $\left(p=\right.$ diopside $\mathrm{Ca}(\mathrm{Mg}, \mathrm{Al})(\mathrm{Si}, \mathrm{Al})_{2} \mathrm{O}_{6}$ and/or augite $\left.\mathrm{Ca}\left(\mathrm{Mg}, \mathrm{Fe}^{3+}, \mathrm{Al}\right)(\mathrm{Si}, \mathrm{Al})_{2} \mathrm{O}_{6}\right)$ crystals together with iron spinels ( $\mathrm{s}=$ magnetite $\mathrm{Fe}_{3} \mathrm{O}_{4}$ and/or magnesioferrite $\mathrm{MgFe}_{2} \mathrm{O}_{4}$ and/or maghemite $\mathrm{Fe}_{2} \mathrm{O}_{3}$ ) as appears evident in Figure 4.

\subsection{Characterization of steel fly ash and glass cullet or grate ash system}

Glass cullet and municipal incinerator grate ash have been used to create the glassy network for the steel waste dust introduced in $10 w t \%$.

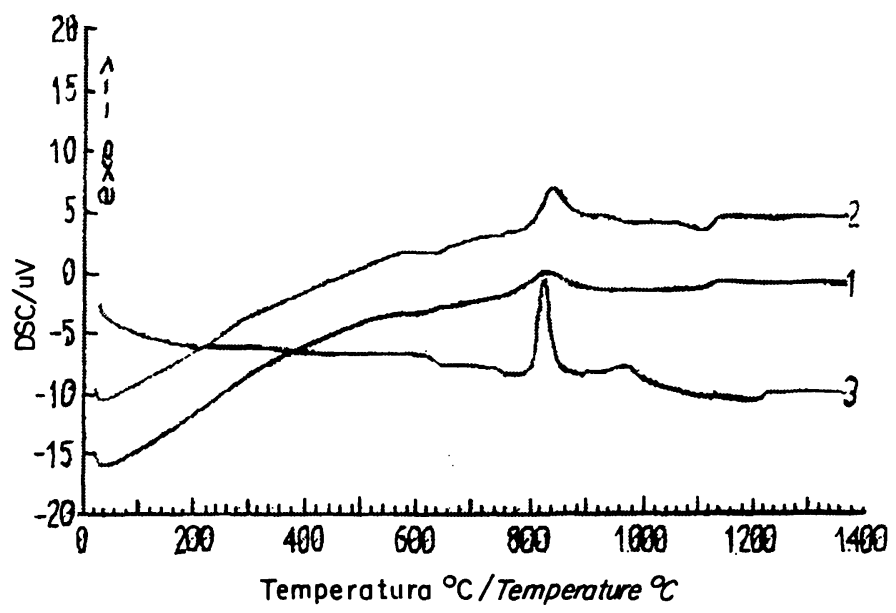

Figura 3.- ATD de mezclas de vidrios, conteniendo: (1) 10,(2) 20 y (3) $30 \%$ en peso de ceniza de carbón.

Figure 3.- DTA runs of the glasses, containing: (1) 10, (2) 20 y (3) 30 wt\% of coal ash.

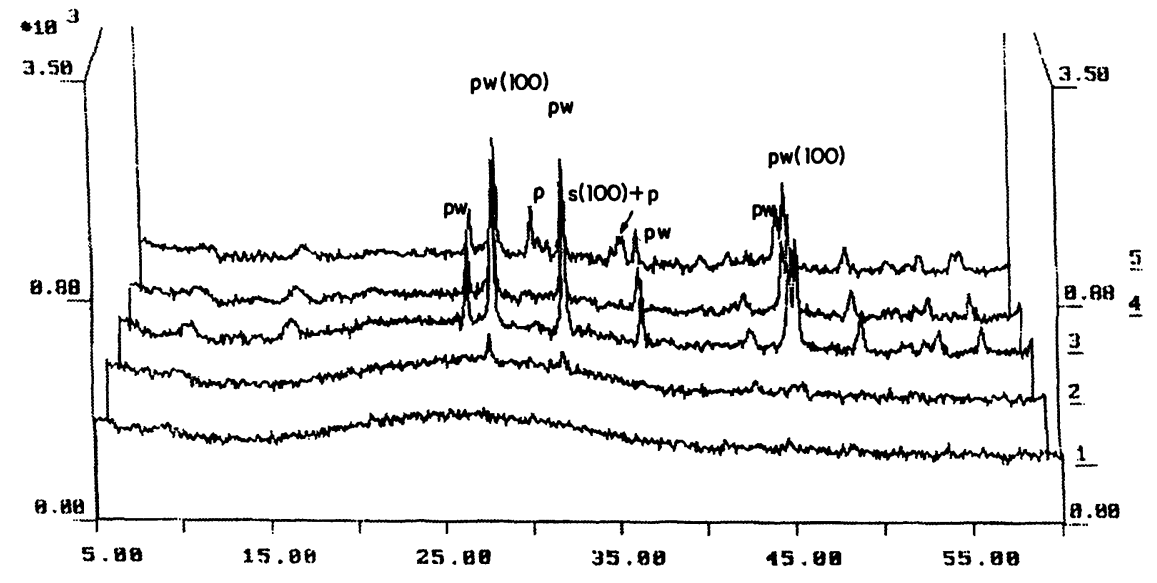

Figura 4.- DRX de materiales vitrocerámicos que contienen desde 10 (1) a $50(5) \%$ en peso de ceniza de carbón tratados a $900{ }^{\circ} \mathrm{C}$ durante 1 hora (pw = pseudowollastonita, $\mathrm{p}=$ piroxeno y $\mathrm{s}=$ espinela.

Figure 4.- XRD patterns of the glass-ceramic materials containing from $10(1)$ to $50(5)$ wt $\%$ of coal ash trated at $900^{\circ} \mathrm{C}$ for 1 hour $(p w=p s e u d o w o l l a s t o n i t e$, $p=$ pyroxene and $s=$ spinel). 
Teniendo en cuenta la naturaleza tóxica de este tipo de residuo, el polvo de acería, los vitrocerámicos se han sometido a una prueba de lixiviado en ácido acético durante $24 \mathrm{~h}$ (11) para simular el comportamiento del vidrio cuando se expone al lixiviado de lluvia y de soluciones percoladas mixtas de tipo orgánico e inorgánico en las escombreras. El comportamiento de vidrios obtenidos con polvos de acería se ha comparado con el de matrices vítreas ( $100 \%$ peso de casco de vidrio y $100 \%$ peso de ceniza de incineradora) como se muestra en la Tabla 3. Esta prueba permite evaluar si la matriz vitrea es capaz de retener con éxito los elementos tóxicos del residuo. Lixiviados muy bajos de elementos metálicos (microcontaminantes) se han obtenido más allá de los límites permitidos por las regulaciones italianas, lo que es una condición necesaria para su uso posterior en el desarrollo de productos comerciales.

Esta prueba requiere un ensayo de inmersión durante 16 días (12) en agua destilada (el agua se renueva en intervalos fijos de tiempo de 2, 8, 24, 48, 72, 102, 168, 384 h). Los lixivados de elementos metálicos más microcontaminantes están por encima de los límites permitidos por las regulaciones italianas (Tabla 4), lo que
By considering the particular hazardous nature of this kind of waste, the steel ash-based glasses have been subjected to a release test in acetic acid for $24 \mathrm{~h}$ (11) to simulate the behavior of the glass when exposed to the leaching both of the rain and of the percolates from organic and inorganic mixed dumps. The behavior of the glasses added with steel dust has been compared to that of the glassy matrices $(100$ $w t \%$ of glass cullet and 100 wt\% of grate ash) as is shown in Table 3. This test enables to evaluate if the glassy matrix is able to retain successfully the wastederived hazardous elements. Very low releases of metallic micro-pollutants were obtained, all very below the limits allowed by the Italian regulations, and this is a necessary condition for their subsequent use in the development of commercial products.

Furthermore also the test which requires 16 days (12) in distilled water (the water is renewed at fixed time ranges of $2,8,24,48,72,102,168,384 \mathrm{~h}$ ) shows releases of metallic micro-pollutants below the limits allowed by the Italian regulations (Table 4) and it is of a significant importance because this test is

\section{TABLA $3 / T A B L E 3$}

Concentración de microcontaminantes (mg/l) en los vidrios estudiados (prueba en ácido acético) comparada con los valores límite / (Metallic micropollutants concentration (mg/l) in the glasses studied (test in acetic acid) compared with the limit values))

\begin{tabular}{|c|c|c|c|c|}
\hline $\begin{array}{c}\text { Composicion (\% peso) } \\
\text { Composition (wt\%) }\end{array}$ & $\mathrm{Cu} 0,05 \mathrm{mg} / 1$ & $\mathrm{~Pb} 0,03 \mathrm{mg} /$ & $\mathrm{Cr}_{\text {to }} 0,05 \mathrm{mg} / 1$ & $\mathrm{Zn} 3 \mathrm{mg} / \mathrm{-}$ \\
\hline $\begin{array}{c}\text { Casco de vidrio } \\
\text { Glass cullet }\end{array}$ & 0,008 & 0,06 & - & 0,118 \\
\hline $\begin{array}{c}\text { Casco de vidrio + ceniza de aceria } \\
\text { Glass cullet + steel ash }\end{array}$ & 0,011 & 0,04 & - & 0,018 \\
\hline $\begin{array}{c}\text { Ceniza de incineradora } \\
\text { Grate ash }\end{array}$ & 0,032 & 0,04 & - & 0,016 \\
\hline $\begin{array}{c}\text { Ceniza de incineradora + ceniza de } \\
\text { aceria } \\
\text { Grate ahs }+ \text { steel ash }\end{array}$ & 0,033 & 0,10 & - & - \\
\hline
\end{tabular}

TABLA 4/TABLE 4

Concentración de microcontaminantes (mg/l) en los vidrios estudiados (16 días de prueba en agua destilada) comparada con los valores límite / (Metallic micropollutants concentration (mg/l) in the glasses studied (16 days test in distilled water) compared with the limit values))

\begin{tabular}{|l|c|c|c|c|}
\hline $\begin{array}{l}\text { Composicion (\% peso) } \\
\text { Composition (wt\%) }\end{array}$ & $\mathrm{Cu} 0,05 \mathrm{mg} / 1$ & $\mathrm{~Pb} \mathrm{0,03} \mathrm{mg/}$ & $\mathrm{Cr}_{\mathrm{rto}} 0,05 \mathrm{mg} / \mathrm{l}$ & $\mathrm{Zn} \mathrm{3} \mathrm{mg/1}$ \\
\hline $\begin{array}{l}\text { Casco de vidrio } \\
\text { Glass cullet }\end{array}$ & 0,025 & 0,015 & - & 0,02 \\
\hline $\begin{array}{l}\text { Casco de vidrio + ceniza de } \\
\text { aceria } \\
\text { Glass cullet + steel ash }\end{array}$ & 0,005 & 0,025 & 0,009 & 0,07 \\
\hline $\begin{array}{l}\text { Ceniza de incineradora } \\
\text { Grate ash }\end{array}$ & 0,008 & 0,010 & 0,04 & 0,04 \\
\hline $\begin{array}{l}\text { Ceniza de incineradora + } \\
\text { ceniza de aceria } \\
\text { Grate ash - steel ash }\end{array}$ & 0,003 & 0,026 & 0,037 & 0,1 \\
\hline
\end{tabular}


es de suma importancia porque esta prueba es particularmente eficiente para producir un cambio de la fase líquida, lo que induce un nuevo equilibrio que condiciona la interfase soluto/solvente, que conduce a una capacidad más alta de extracción de la solución.

El efecto de la introducción del polvo de acería depende del tipo de matriz considerada. De hecho, la adición de ceniza volante en el casco de vidrio induce el inicio de la cristalización sobre los $800^{\circ} \mathrm{C}$ gracias al efecto del hierro. En lo que concierne a la ceniza produce una disminución de unos $15-20^{\circ} \mathrm{C}$ en la temperatura de transición vítrea cuando se introduce en la composición un $10 \%$ peso de ceniza de acería a causa del efecto de los óxidos de $\mathrm{Na}_{2} \mathrm{O}$ y $\mathrm{ZnO}$ de modificador, mientras la temperatura de cristalización cambia hacia un valor más bajo $\left(\Delta \mathrm{T}=70^{\circ} \mathrm{C}\right)$, debido al óxido de hierro que actúa como agente nucleante. Este último óxido es también responsable del segundo pico exotérmnico cerca de los $990^{\circ} \mathrm{C}$ debido a la formación de fases cristalinas de hierro.

La conclusión que se deduce de los datos térmicos se confirma por DRX (Figura 5). Un tratamiento térmico a $900^{\circ} \mathrm{C}$ prolongado durante $16 \mathrm{~h}$ (curvas 1 y 2 de esta figura) no modifica la naturaleza amorfa del casco de vidrio, mientras que favorece un comienzo de la cristalización en el material obtenido con polvo de acería, dando lugar a wollastonita, maghemita y diópsido. Por otra parte, la ceniza volante de acería actúa como un catalizador para el proceso de cristalización de ceniza de incineradoras municipales (curvas 3 y 4 en la misma figura), promoviendo la precipitación de cristales conteniendo hierro. Las fases cristalinas principales presentes en los vitrocerámicos obtenidos a partir la adición de polvo de acería son: anortita rica en sodio, augita, diópsido y wollastonita; así como la adición de : franklinita $\left(\mathrm{ZnFe}_{2} \mathrm{O}_{4}\right)$ reemplazando a la anortita de sodio y a la wollastonita. particularly efficient in that, providing the change of the liquid phase at different times, it induces the reestablishment of a new equilibrium condition at the interface solute/solvent, which leads to a higher extraction capability of the solution.

The effect of the steel dust introduction depends on the kind of the matrix considered. In fact the addition of fly ash into the glass cullet induces a beginning of crystallization at about $800^{\circ} \mathrm{C}$ thanks to the iron effect. As for the bottom ash-containing sample a slight decrease of about $15-20^{\circ} \mathrm{C}$ in the glass transition temperature is observed when a $10 \mathrm{wt} \%$ of steel ash is introduced because of the effect of $\mathrm{Na}_{2} \mathrm{O}$ and $\mathrm{ZnO}$ modifier oxides, while the crystallization temperature shifts toward a lower value $\left(\Delta T=70^{\circ} \mathrm{C}\right)$, due to the iron oxide nucleating effect. This last oxide is also responsible for a second exothermic peak near $990^{\circ} \mathrm{C}$ due to the formation of iron crystalline phases.

The conclusion drawn by the thermal data are confirmed by XRD analysis (Figure 5). A thermal treatment at $900^{\circ} \mathrm{C}$ prolonged for $16 \mathrm{~h}$ (curves 1 and 2 in the figure) does not modify the amorphous nature of the glass cullet, while it promotes a beginning of crystallization in the steel-containing sample developing wollastonite, maghemite and diopside. On the other hand the steel fly ash acts as a catalyst for the crystallization process in the municipal incinerator grate ash matrix (curves 3 and 4 in the figure) promoting the precipitation of ironcontaining crystals. The main crystalline phases present in the grate ash glass ceramics are sodian anorthite sodian, augite, diopside and wollastonite; after the addition of the steel fly ash, iron oxides and franklinite $\left(\mathrm{ZnFe}_{2} \mathrm{O}_{4}\right)$ replace sodium anorthite and wollastonite.

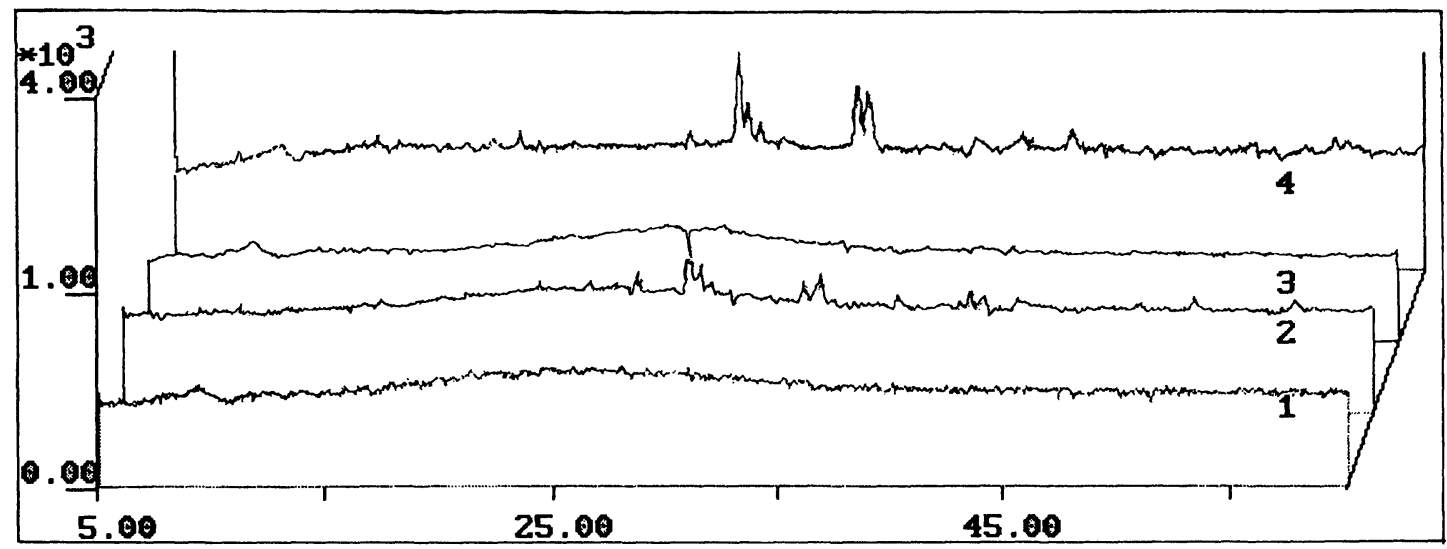

Figura 5.- DRX de materiales vitrocerámicos de (1) casco de vidrio y (2) casco de vidrio $+10 \%$ en peso de polvo de aceria tratado a $900{ }^{\circ} \mathrm{C}$ durante 16 horas; (3) ceniza de incineradora y (4) ceniza de incineradora $+10 \%$ peso de polvo de acería tratado a $1.000^{\circ} \mathrm{C}$ durante 1 hora.

Figure 5.- XRD patterns of (1) glass cullet and (2) glass cullet plus 10 wt\% of steel dust samples treated ast $900{ }^{\circ} \mathrm{C}$ for 16 hours; (3) grate ash and (4) grate ash plus 10 wt\% of steel dust samples treated at $1.000{ }^{\circ} \mathrm{C}$ for 1 hour. 


\section{CONCLUSIONES GENERALES}

Los resultados recogidos en esta revisión subrayan la posibilidad de considerar la vitrificación como una técnica apropiada y eco-compatible, alternativa para la recuperación de residuos como la solución más común al almacenamiento en vertederos o en depósitos (balsas), incluso en el caso de los controlados. Además, la capacidad de muchos vidrios investigados para ser transformados en materiales semicristalizados (vitrocerámicos) se podría explotar como un desarrollo adicional a la técnica de vitrificación. Basándose en la composición química de los diferentes tipos de residuos es posible adaptar las mezclas más apropiadas para ser vitrificables y no se puede desechar la posibilidad para predecir la cristalización teóricamente por cálculos a partir de los diagramas de equilibrio entre fases. Las propiedades de diferentes materiales vítreos y vitrocerámicos estrictamente dependen de la naturaleza del residuo a causa del papel que juegan los diferentes elementos contenidos en los mismos en la formación de la red vítrea.

\section{GENERAL CONCLUSIONS}

The results reported in this review underline the possibility to consider the vitrification technique a suitable and eco-compatible waste recovery alternative with respect to the most common solution of the land-filling. Furthermore the capability of many glasses here investigated to be transformed into semi-crystallized materials (glass-ceramics) can be exploited as a further development to the vitrification technique. On the basis of the chemical composition of the different kinds of wastes it is possible to tailor the batches most suitable to be vitrifiable and of non negligible consideration is the possibility to predict the crystallization capability of the systems by mathematical approaches. The different properties of the waste-based glasses and glass-ceramics are strictly dependent on the nature of the waste because of the role played by the different elements presents.

\section{BIBLIOGRAFÍA}

(1) R. Cioffi, P. Pernice, A. Aronne, M. Catauro and G. Quattroni: Glass-ceramics from Fly Ash with Added Li 2 O. J. Europ. Ceram. Soc., Vol.13(1994)pp. 143-148.

(2) A.R. Boccaccini, M. Bucker and J. Bossert: Glass and Glass-ceramics from coal fly-ash and waste glass. Tile and Bricks, Vol.12 [6] (1996)pp.515-518.

(3) L. Barbieri, T. Manfredini, I. Queralt, J.Ma. Rincón and M. Romero: Vitrification of Fly Ash from Thermal Power Stations. Glass Technology, Vol.38[5](1997),pp.165-170.

(4)L. Barbieri, ILancellotti, T. Manfredini, I. Queralt, J.Ma. Rincón and M. Romero: Design, Obtainment and Properties of Glasses and Glassceramics from Coal Fly Ash. Fuel, Vol.78(1999), pp. 271-276

(5) L. Barbieri, A. Corradi I. Lancellotti: Bulk and sintered glass-ceramics by recycling municipal incinerator bottom ash. J. Europ. Ceram. Soc., Vol.20[10](2000)pp.1637-1643.

(6) L. Barbieri, A. M. Ferrari, I. Lancellotti, C. Leonelli, J. Ma. Rincòn and M. Romero: Crystallization of $\left(\mathrm{Na}_{2} \mathrm{O}-\mathrm{MgO}\right)-\mathrm{CaO}-\mathrm{Al}_{2} \mathrm{O}_{3}-\mathrm{SiO}{ }_{2}$ glassy systems formulated from waste products. J. Am. Ceram. Soc., Vol. 83[10] (2000), pp. 2515-2520.

(7)L. Barbieri, A. Corradi Bonamartini and I. Lancellotti: Alkaline and alkaline-earth silicate glasses and glass-ceramics from municipal and industrial wastes. J. Europ. Ceram. Soc., Vol. 20[14-15](2000), pp. 2477-2483.

(8) M. Puccio. Le ceneri di carbone. p. 7, Ed by ITEC, Milan, 1983.

(9) R. Bersani and U. Pretato "Il riciclo del vetro e il problema del contenuto dei metalli pesanti: scenario italiano e confronto con i principali Paesi europei”. Proceedings of RICICLA '99, Rimini, Italia, 21-24 octubre 1999. pp 220-224

(10) A. García Verduch, in Proceedings of the Jornadas Científicas sobre Ceramica y Vidrio, Ed. Univ. de Oviedo. Oviedo, 1980 p. 120.

(11) Italian Regulations D.I. 14 julio 1986.

(12) Italian Official Gazette 14.04.98.

Nota de redacción

El Comité de Redacción de la Revista agradece a D. José María Rincón la traducción al español y la revisión técnica del manuscrito. 